\title{
Placenta is Capable of Protecting the Male Fetus from Exposure to Environmental Bisphenol A
}

\author{
Monika Lukasiewicz ${ }^{1}$ Jan Czerniecki ${ }^{2}$. Donata Ponikwicka-Tyszko ${ }^{2} \cdot$ Maria Sztachelska $^{2} \cdot$ Marta Hryniewicka $^{3}$. \\ Edyta Nalewajko-Sieliwoniuk ${ }^{4} \cdot$ Wieslaw Wiczkowski ${ }^{5} \cdot$ Beata Banaszewska $^{6} \cdot$ Robert Milewski $^{7} \cdot$ Jorma Toppari $^{8,9}$. \\ Ilpo Huhtaniemi ${ }^{10} \cdot$ Nafis A. Rahman ${ }^{1,8}$. Slawomir Wolczynski ${ }^{1,2}$ (])
}

Received: 13 September 2019 / Revised: 25 March 2020 / Accepted: 2 May 2020 / Published online: 15 May 2020

(c) The Author(s) 2020

\begin{abstract}
Embryo-fetal exposure to bisphenol A (BPA) could be related to poor male reproductive parameters in rodents, but this concept has not been convincingly confirmed in humans. We investigated the association of environmental BPA exposure of pregnant women with selected endocrine and anthropometric parameters of male newborns. We analyzed plasma BPA from pregnant mothers, umbilical cord, and placental tissues ( $n=117 /$ each group) by liquid chromatography and mass spectrometry. LH, FSH, AMH, TGF $\beta 2$, inhibin B, and selected sex steroids were measured in cord plasma. The infant anthropometric parameters included anogenital distance, stretched penile length, head circumference, birthweight, and length. The median BPA concentrations in maternal and umbilical cord plasma, and in placental tissue were 19.0, 8.0, and $22.2 \mathrm{nmol} / \mathrm{L}$, respectively, the levels thus being over twofold lower in the fetal circulation than in the mother or placenta. The BPA concentrations measured were 100-1000-fold lower than those demonstrated in animal experiments to have endocrine disrupting effects. Multivariable regression analysis indicated no significant correlations between the maternal/fetal/placental BPA concentrations and any of the hormone levels or anthropometric parameter measured. Plasma concentrations of BPA confirmed both maternal, placenta, and fetal exposure to environmental BPA, but the concentrations were orders of magnitude lower than those with documented endocrine disrupting activity. Moreover, the maternal/fetal concentration gradient as well as the lack of correlations of BPA levels with any major endocrine or anthropometric parameters measured in the newborns suggest a protective role for the placenta in reducing fetal exposure to the environmental BPA.
\end{abstract}

Keywords Bisphenol A $\cdot$ Environmental exposure $\cdot$ Pregnancy $\cdot$ Male fetus $\cdot$ Placenta

\section{Introduction}

Endocrine disrupting chemicals (EDCs) are synthetic or natural molecules that may interfere with the body's endocrine system and produce developmental, reproductive, neurological, and immune effects ( $\mathrm{Li}$ et al. 2015). Many EDCs possess estrogenic, anti-estrogenic, or anti-androgenic activity

Nafis A. Rahman and Slawomir Wolczynski have contributed equally to this work.

Electronic supplementary material The online version of this article (https://doi.org/10.1007/s12403-020-00358-5) contains supplementary material, which is available to authorized users.

Slawomir Wolczynski

endorepro@umb.edu.pl

Extended author information available on the last page of the article
(Combarnous and Nguyen 2019), which may affect the reproductive system. They have been potentially associated with the impairments of the male reproductive system such as cryptorchidism and hypospadias, the testicular dysgenesis syndrome, and decreased semen quality (Carlsen et al. 1992; Jorgensen et al. 2012; Mathews and Hamilton 2005; Skakkebaek et al. 2001, 2016); Toppari et al. 1996, 2010). In numerous animal studies, EDCs acted as estrogen receptor antagonists and showed adverse effects on testicular development and function of the hypothalamic-pituitary-testicular axis (Doshi et al. 2011; Fenichel et al. 2013; Gould et al. 1998; Liu et al. 2013; Nakamura et al. 2010). Data on major harmful effects of EDCs on humans cannot as yet be considered convincing.

Among the EDCs, bisphenol A (BPA) is regarded as the most common and is by far the most studied EDC (Sharpe and Irvine 2004) (over 12,000 hits in PubMed). BPA is 
mostly found in plastic products (water bottles, CDs, DVDs, and medical equipment) and epoxy resins (water pipe and beverage can linings), and it easily leaches out of cans, microwavable containers, dental sealants, and polycarbonate bottles during normal use (Allard 2011; Rochester 2013; Rubin 2011; Vandenberg et al. 2007). BPA binds to estrogen receptors (both nuclear and membrane receptors such as GPR30) with similar affinity ( $\left.\mathrm{Kd} 10^{-6} \mathrm{M}\right)$ as estradiol (E2) binds to membrane estrogen receptors (Gould et al. 1998; Molina-Molina et al. 2013; Routledge et al. 2000). There is a growing concern regarding BPA exposure in the general population (including children and pregnant women) (Huo et al. 2015; Vandenberg 2014; vom Saal et al. 2007). The National Toxicology Program and the Food and Drug Administration (FDA) first banned BPA use in baby bottles (FDA 2012a, b); however, later on, they have amended the regulations [https://www.federalregister.gov/docum ents/2012/07/17/2012-17366/indirect-food-additives-polym ers], as companies no longer use BPA-based polycarbonate resins in baby bottles. In 2015, the European Food Safety Authority (EFSA) announced that the BPA used in the production of plastic and the BPA present in the environment was safe for humans, although they reduced the BPA safety level from 50 to $4 \mu \mathrm{g} / \mathrm{kg}$ body weight/day [https://www.efsa. europa.eu/en/press/news/150121].

Exposure to BPA, even at low doses, has been implied to pose a health risk (), while others suggest that human exposure is lower than the harmful BPA concentrations (Calafat 2012; Vandenberg et al. 2007) [https://www.efsa. europa.eu/en/press/news/171214; CLARITY--BPA project]. Nevertheless, in all these cases, the exposure levels were at high-nano to micromolar concentrations. Epidemiological studies and clinical observations have found that male fertility has declined over the past few decades (Vandenberg et al. 2007; Virtanen et al. 2017), e.g., in some studies sperm counts have decreased by $50 \%$ in the last 50 years (Carlsen et al. 1992). Moreover, BPA, similar to some other EDCs (e.g., diethylstilbestrol, DES) (McLachlan et al. 1975), may elevate the ratio of estrogenic/androgenic activity during the male programing window (MPW) for fetal testicular masculinization during prenatal development (Fenichel et al. 2013; Rochester 2013; Rubin 2011; Shelnutt et al. 2013; Skakkebaek et al. 2001, 2016). This may cause persistent changes in spermatogenesis and testicular steroidogenesis in adult life (Skakkebaek et al. 2001, 2016). Animal studies with in vivo exposure suggest that at doses exceeding normal environmental exposure, BPA affects male reproductive development and may cause testicular dysgenesis and atrophy, enlargement of the prostate gland, decreased AGD, and changes in semen parameters (Lee et al. 2018). Moreover, BPA may influence the hypothalamic-pituitary-testicular axis and the secretion of gonadotropins and steroid hormones, and alter their receptor expression (Anjum et al. 2011; Arase et al. 2011; Fenichel et al. 2013; Jin et al. 2013; LaRocca et al. 2011; Medwid et al. 2016; Nakamura et al. 2010; Tyl et al. 2008; Vrooman et al. 2015; Wang et al. 2010; Xi et al. 2011). BPA actions are not only limited to fetuses and adults but could also be passed on to future generations through epigenetic effects (Skinner 2011a, b, c). The question of whether environmental BPA exposure is sufficient to influence testicular development and male fertility in humans remains contentious.

Herein, we revisited the potential effects of environmental BPA exposure in pregnant women, and consequently checked the possible associations of environmental BPA exposure with a number of parameters related to function of the hypothalamic-pituitary-testicular axis of male fetuses and newborns. We also investigated whether the placenta could be capable of reducing BPA transport from the mother to the fetus, thus potentially protecting the male fetus from environmental BPA exposure.

\section{Materials and Methods}

\section{Study Design}

The inclusion criteria of pregnant mothers for this study were a singleton male pregnancy, consent to well-informed participation and willingness to complete a detailed questionnaire. The exclusion criteria were as follows: any severe chronic disease (e.g., diabetes, hypertension, or thyroid pathology) and the development of any disease-related pathology due to pregnancy that may affect fetal development or growth. One hundred and seventeen pregnant Caucasian women $(n=117$, nulliparous $n=57$, multiparous $n=60$ ) fulfilling the inclusion criteria took part in the present study. The participants were questioned about their prior medical history, eventual occupational BPA exposure, age, socioeconomic status, and weight before pregnancy and at delivery. Gestational age was estimated based on the first day of the last menstrual cycle or the first ultrasound.

The primary measure of the socioeconomic status was weighted income quintile calculated from total family income in the country, adjusted for family size using the Organization for Economic Co-operation and Development's equivalency scale. (Development 2015; Martinson and Reichman 2016). We also considered maternal education coded as less than high school or equivalent, high school or equivalent, some postsecondary education or college, and at least a college education, as an additional measure of socioeconomic status (Pilkauskas and Martinson 2014). 


\section{Anthropometric Parameters}

Anthropometric parameters were evaluated in male newborns, including the anogenital distance (AGD see below), the stretched penile length (SPL), the head circumference, and the birthweight and length, as described earlier (Fenichel et al. 2012). A digital caliper, with a measuring range: $0-150 \mathrm{~mm} / 0-6 "$, resolution: $0.01 \mathrm{~mm} / 0.0005 "$, accuracy: $\pm 0.02 \mathrm{~mm} / \pm 0.008^{\prime \prime}[\mathrm{https}: / / \mathrm{www}$. cromwell.co.uk/ shop/measuring-and-test-equipment/digital-calipers/polyc al-digital-caliper-0-150mm-0-6inch/p/SEN3311700K], was used for all measurements. AGD was measured by placing the infants in a dorsal decubitus position, with spread legs and bent knees. Infants were measured from the center of the anus to the anterior base of the penis (AGDap) and from the center of the anus to the anterior base of the scrotum (ASDas). Two measurements were taken to minimize errors. SPL was assessed by measuring the distance from the penile base under the pubic symphysis to the tip of the glans. Birthweight was measured with a calibrated digital scale. External genitalia were examined using an orchidometer, including urethral orifice positioning and testicular positioning and size.

Peripheral blood was obtained from 117 mothers during admission to hospital for delivery $(\sim 38-41$ th week of pregnancy), in order to avoid the hospital-stay effects in relation to BPA exposures/contaminations. Hospital-stay contaminations could depend on BPA in the hospital dietary sources or eating/drinking containers. Cord venous blood was obtained from 117 male newborns at the time of delivery. All blood samples were collected in BPA-free tubes with EDTA (Corning Incorporated, NY, \# catalog number MCT200-L-C), plasma was isolated by centrifugation, and stored at $-80{ }^{\circ} \mathrm{C}$. Ten pieces of $0.5 \mathrm{~cm}$ placental trophoblast tissue were collected from random locations of each placenta, pooled and placed in the same polycarbonate and BPA-free tubes as above. Special attention was paid to avoiding any type of cross-contaminations during the sample collection and storage processes.

The research project was approved by the ethics committee of The Centre for Postgraduate Medical Studies in Warsaw 5/PB/2013/CKMP, and participants signed written consent for participation in the study. Approval of the ethics committee for taking newborn blood samples was not granted.

\section{Analytical Methods}

\section{BPA Measurement from the Umbilical Cord and Mater's Blood Plasma}

Bisphenol A was measured from thawed at room temperature plasma samples. BPA was extracted three times from the samples, using sonication in acetonitrile and vortex mixing. The collected supernatants were first centrifuged for $10 \mathrm{~min}$ at $5000 \mathrm{~g}$ and then evaporated at $37{ }^{\circ} \mathrm{C}$ under nitrogen atmosphere until complete solvent evaporation. The formed solids were then dissolved in methanol and injected in into UHPLC microcolumns coupled with a mass spectrometer (TripleTOF 5600+ mass spectrometer, AB SCIEX, US). Deuterated BPA was used as an internal standard. The BPA concentrations were calculated using a calibration curve for concentrations from 0 to $4.3 \mathrm{nmol} / \mathrm{L}$.

\section{BPA Extraction from the Placental Trophoblast Tissues}

The placental fragments collected after delivery were snapfrozen and stored at $-80{ }^{\circ} \mathrm{C}$, thawed when needed at room temperature, and homogenized in $0.01 \mathrm{~mol} / \mathrm{L}$ ammonium acetate buffer $\mathrm{pH} 4.5$ with methanol and $4 \mathrm{~mol} / \mathrm{L}$ perchloric acid. The homogenates were then vortexed and centrifuged at $4{ }^{\circ} \mathrm{C}$ and $5000 \mathrm{~g}$ for $10 \mathrm{~min}$. The supernatants were extracted using preconditioned SPE C18 columns (Solid Phase Extraction). BPA was eluted from the BEADS with a solution of diethyl ether and methanol at a volume ratio of 9:1. The eluates were evaporated at $37{ }^{\circ} \mathrm{C}$. The pellets were dissolved in methanol and injected into UHPLC microcolumns coupled with a mass spectrometer (TripleTOF $5600+$ mass spectrometer, AB SCIEX, US). Deuterated BPA was used as an internal standard. The BPA concentrations were calculated using a calibration curve for concentrations from 0 to $4.3 \mathrm{nmol} / \mathrm{L}$.

\section{AMH Measurements}

An infinite M200 Pro microplate reader (Tecan, Tecan Group Ltd., Männedorf, Switzerland) was used to detect anti-Müllerian hormone (AMH), together with AMH Gen II ELISA (Beckman Coulter CA, U.S.A.), following the manufacturer's (Beckman Coulter) instructions. Before measurement, the samples were thawed to room temperature and diluted tenfold in the AMH Gen II Sample Diluent supplied in the kit. The AMH concentration was calculated using the calibration curve for concentrations between 0 and $0.16 \mathrm{nmol} / \mathrm{L}$.

\section{Inhibin B Measurements}

The Inhibin B EIA Kit (Sigma-Aldrich, St. Louis, MO, USA) was used to detect inhibin B, following the manufacturer's instructions. Absorbance at $450 \mathrm{~nm}$ was measured with an Infinite M200 Pro microplate reader (Tecan). Inhibin B concentration was calculated using the calibration curve for concentrations between 0 and $7.14 \mathrm{nmol} / \mathrm{L}$. 


\section{TGF- $\beta 2$ Measurements}

The human TGF- $\beta 2$ ELISA Kit (Sigma-Aldrich) was used to detect transforming growth factor-beta 2, according to the manufacturer's instructions. An Infinite M200 Pro microplate reader (TECAN) was then used to measure absorbance at $450 \mathrm{~nm}$. The TGF- $\beta 2$ concentration was calculated using calibration concentrations between 0 and $125 \mu \mathrm{mol} / \mathrm{L}$.

\section{Testosterone and Androstenedione Measurements}

Methyl tert-butyl ether was used to extract the steroid hormones. The organic fractions were then evaporated under a nitrogen atmosphere at $50{ }^{\circ} \mathrm{C}$ to complete dryness. The residue was dissolved in a derivatization solution $(0.7 \mathrm{M}$ hydroxylamine dissolved in a methanol/water solution, volume ratio $3: 7$ ) and incubated at $70{ }^{\circ} \mathrm{C}$ for $1 \mathrm{~h}$. Before analysis, the same volume of water was added to the samples. Steroid hormone levels were assessed using liquid chromatography coupled with tandem mass spectrometry (LC-MS/MS) using the Shimadzu LCMS/MS 8040 kit. A Kinetex 5 u EVO C18 100A $100 \times 2.1 \mathrm{~mm}$ column was used for separation. A water/methanol solution gradient was the separating mobile phase; $10 \mathrm{mM}$ of formic acid (from 15 to $97 \%$ methanol for $1.5 \mathrm{~min}$ ) was added to both solvents. Testosterone and androstenedione were identified by the retention time and typical fragmentation spectrum in the positive ion mode. Deuterated steroid hormones were used as internal standards. The testosterone and androstenedione concentrations were calculated using calibration curve for concentrations from 0 to $50 \mathrm{nmol} / \mathrm{L}$.

\section{Statistical Analysis}

The normality of distribution was tested using the Shapiro-Wilk test. There was no normal distribution in any of the analyzed quantitative features. Thus, to characterize the analyzed quantitative variables, the median and quartile (Q1 and Q3) indicators were used. The non-parametric Friedman test with adjusted post hoc Conover test was used to compare BPA concentrations among the maternal, placental, and umbilical cord plasma samples. Due to their high variations, BPA concentrations and umbilical cord plasma inhibin B levels were transformed to logarithmic scale. The Spearman's rank test was used to determine the correlation coefficient between the analyzed quantitative variables. A $p$ value lower than 0.05 was considered statistically significant. Statistica 12.0 Software (StatSoft, Tulsa, OK) was used for biostatistical calculations.
Table 1 Clinical characteristics of mothers

\begin{tabular}{ll}
\hline$N=117$ & Median $(\mathrm{Q} 1-\mathrm{Q} 3)$ \\
\hline Maternal age & $31.0(29.0-33.0)$ \\
Weight before pregnancy $(\mathrm{kg})$ & $61.5(56.0-69.0)$ \\
Weight at delivery $(\mathrm{kg})$ & $76.0(69.5-84.0)$ \\
Height $(\mathrm{cm})$ & $167(164-171)$ \\
BMI before delivery $\left(\mathrm{kg} / \mathrm{m}^{2}\right)$ & $21.9(20.2-24.3)$ \\
BMI at delivery $\left(\mathrm{kg} / \mathrm{m}^{2}\right)$ & $27.4(25.1-30.0)$ \\
BMI change $\left(\mathrm{kg} / \mathrm{m}^{2}\right)$ & $4.7(4.1-5.7)$ \\
\hline
\end{tabular}

Table 2 Clinical characteristics of male newborns

\begin{tabular}{ll}
\hline$N=117$ & Median (Q1-Q3) \\
\hline Birthweight (g) & $3520(3280-3860)$ \\
Birth length (cm) & $51.0(48.0-54.0)$ \\
Head circumference (cm) & $34.0(33.0-35.0)$ \\
AGDas (mm) & $25.4(22.9-27.2)$ \\
AGDap (mm) & $52.7(50.6-55.9)$ \\
SPL (mm) & $22.4(19.9-24.4)$ \\
\hline
\end{tabular}

ASDas distance from the center of the anus to the anterior base of the scrotum, AGDap, anus to the anterior base of the penis (AGDap), $S P L$ the distance from the penile base under the pubic symphysis to the tip of the glans

\section{Results}

Tables 1 and 2 feature the general characteristics of the pregnant women and their male newborns, respectively. Briefly, the mothers had a narrow age range (29-33 years) and only $\sim 5 \%$ of them had BMI $>24$. The median BMI increase during pregnancy was 4.7 (Table 1). Approximately $48 \%$ of the women were expecting their first child. The majority of the women $(n=68)$ had their children delivered by Caesarian sections and 48 delivered by vaginal birth (37-42 weeks of gestation), all without fetal anomalies (Table 2). The birthweights ranged between 3.2 and $3.8 \mathrm{~kg}$ with a median of $3.5 \mathrm{~kg}$. Birth lengths, head circumferences, AGDas, AGDap, and SPLs as median and quartiles (Q1 and Q3) are shown in Table 2.

BPA concentrations were measured in maternal blood in late pregnancy (during the time of admission to hospital for delivery) and umbilical cord vein collected during delivery, as well as in placental tissue extracts (Fig. 1). There was a statistically significant $(p<0.001)$ difference between serum BPA concentrations in maternal plasma $v s$. placental tissue $(p<0.05)$, and maternal plasma $v s$. cord plasma $(p<0.001)$ by post hoc analysis (Fig. 1$)$. The highest BPA concentration was observed in placental tissues, with a median value of $22.3 \mathrm{nmol} / \mathrm{kg}(\mathrm{Q} 1=17.4 \mathrm{nmol} / \mathrm{kg}$, $\mathrm{Q} 3=37.0 \mathrm{nmol} / \mathrm{kg}$ ). A lower concentration was detected 


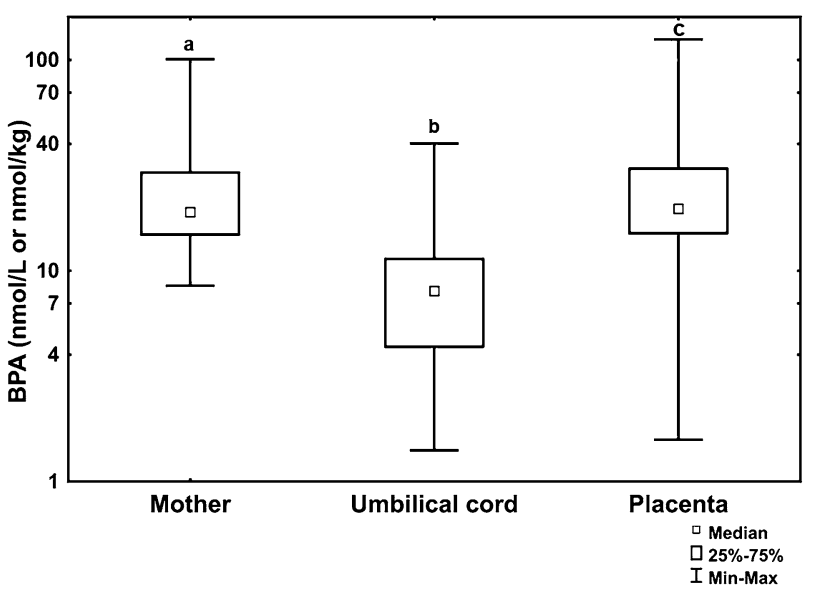

Fig. 1 BPA concentrations measured in the maternal and umbilical cord plasma, and in placental samples ( $n=117 /$ each group). The plasma BPA concentrations are $\mathrm{nmol} / \mathrm{L}$; those in placental tissue $\mathrm{nmol} / \mathrm{kg}$; logarithmic scale. Different small letters $(\mathrm{a}, \mathrm{b})$ above the bars indicate significant differences between groups $(p<0.001)$

in maternal plasma $[19.0 \mathrm{nmol} / \mathrm{L}(\mathrm{Q} 1=14.9 \mathrm{nmol} / \mathrm{L}$, $\mathrm{Q} 3=29.3 \mathrm{nmol} / \mathrm{L})]$, and the lowest BPA concentration was detected in cord plasma $[8.01 \mathrm{nmol} / \mathrm{L}(\mathrm{Q} 1=4.4 \mathrm{nmol} / \mathrm{L}$, $\mathrm{Q} 3=11.4 \mathrm{nmol} / \mathrm{L})]$ (Fig. 1). A significant pair correlation $(R=0.39)(p<0.01)$ between maternal plasma vs. placental tissue could be found, although no paired correlations existed between the mother vs. umbilical cord or umbilical cord vs. placental tissue BPA concentration levels (Suppl. Fig. 1).

There were no significant correlations between the maternal plasma BPA and umbilical cord plasma hormone concentrations (testosterone, androstenedione, AMH, FSH, inhibin B, and TGF- $\beta 2$ ) (Fig. 2 and Suppl. Fig. 1). Neither was there correlation between umbilical cord plasma BPA concentrations and AGDas, AGDap, newborn penis length, and newborn head circumference (Fig. 3).

We did not find any significant correlation between the placental tissue BPA concentrations and cord plasma hormones or anthropometric parameters (Fig. 4). No correlations between the placental BPA concentrations and the assessed hormone levels in umbilical cord plasma were found (Suppl. Figs. 2-4).

\section{Discussion}

\section{Pregnant women and newborns were exposed to BPA}

Some studies suggest that the elevated serum BPA levels ranging from 2.0 to $32.6 \mathrm{nmol} / \mathrm{L}$ (Chou et al. 2011; Ikezuki et al. 2002; Kuroda et al. 2003; Schonfelder et al. 2002;
Shekhar et al. 2017) are not due to environmental exposure but rather to contamination during blood sampling (Teeguarden et al. 2016). We trust this is not the case with our samples because they were collected with BPA-free equipment. We confirmed that all the examined pregnant women were exposed to environmental BPA, with a median concentration of $19.0 \mathrm{nmol} / \mathrm{L}$ in maternal peripheral plasma, in line with the earlier reports (Chou et al. 2011; Ikezuki et al. 2002; Kuroda et al. 2003; Schonfelder et al. 2002; Shekhar et al. 2017). Administration of a massive PBA dose, $100 \mu \mathrm{g} /$ $\mathrm{kg}$ body weight orally with food in a single dose, caused the maximum blood plasma concentration of unconjugated BPA of $6.5 \mathrm{nmol} / \mathrm{L}$ (Thayer et al. 2015). This concentration was lower than observed in our analyses, possible due to saturation of the BPA transport from the gut. However, the kinetics of BPA absorption in human digestive track has not been well studied, and only a part of this compound was apparently absorbed. People are rarely exposed to high single doses of BPA, and typical exposure occurs from low doses absorbed constantly (when environment and dietary habits remain constant). Therefore, the saturation of BPA transport is rare, and plasma concentration may reach higher values. Due to strict criteria of avoiding "hospital-stay" effects in relation to EDC exposure (hospital dietary sources or eating/drinking containers with BPA), we could exclude the additional source of contamination. In our study, the median BPA concentration in maternal peripheral plasma was more than twofold higher than in cord blood. Earlier studies suggest that fetuses and newborns are exposed to BPA as well, with a wide concentration range from 2.2 to $10.1 \mathrm{nmol} / \mathrm{L}$ in cord blood (Chou et al. 2011; Kolatorova et al. 2018; Lee et al. 2018; Yamamoto et al. 2016). Some studies have shown significantly higher BPA levels in cord than maternal blood (Kolatorova et al. 2018; Lee et al. 2018), whereas others observed no correlation between maternal and fetal blood levels of BPA (Chou et al. 2011; Yamamoto et al. 2016).

It has been suggested that BPA may pose a potential risk for the developing fetus due to its higher sensitivity to chemical factors than of adult organs (Gatimel et al. 2016). In this study, we revisited the exposure in pregnant women and male fetuses to BPA. The novelty of our study lies in the simultaneous measurement of BPA levels in maternal and umbilical cord vein blood, and placental tissue, and assessment of their potential associations with several endocrine parameters related to the hypothalamic-pituitary-testicular function of male fetuses and newborns, as well as with several important anthropometric parameters. Some studies showed that BPA urinary level is higher than in blood plasma because the BPA is mainly removed from the body with urine (Calafat 2012). However, in our study, we decided to analyze the maternal plasma BPA concentration 

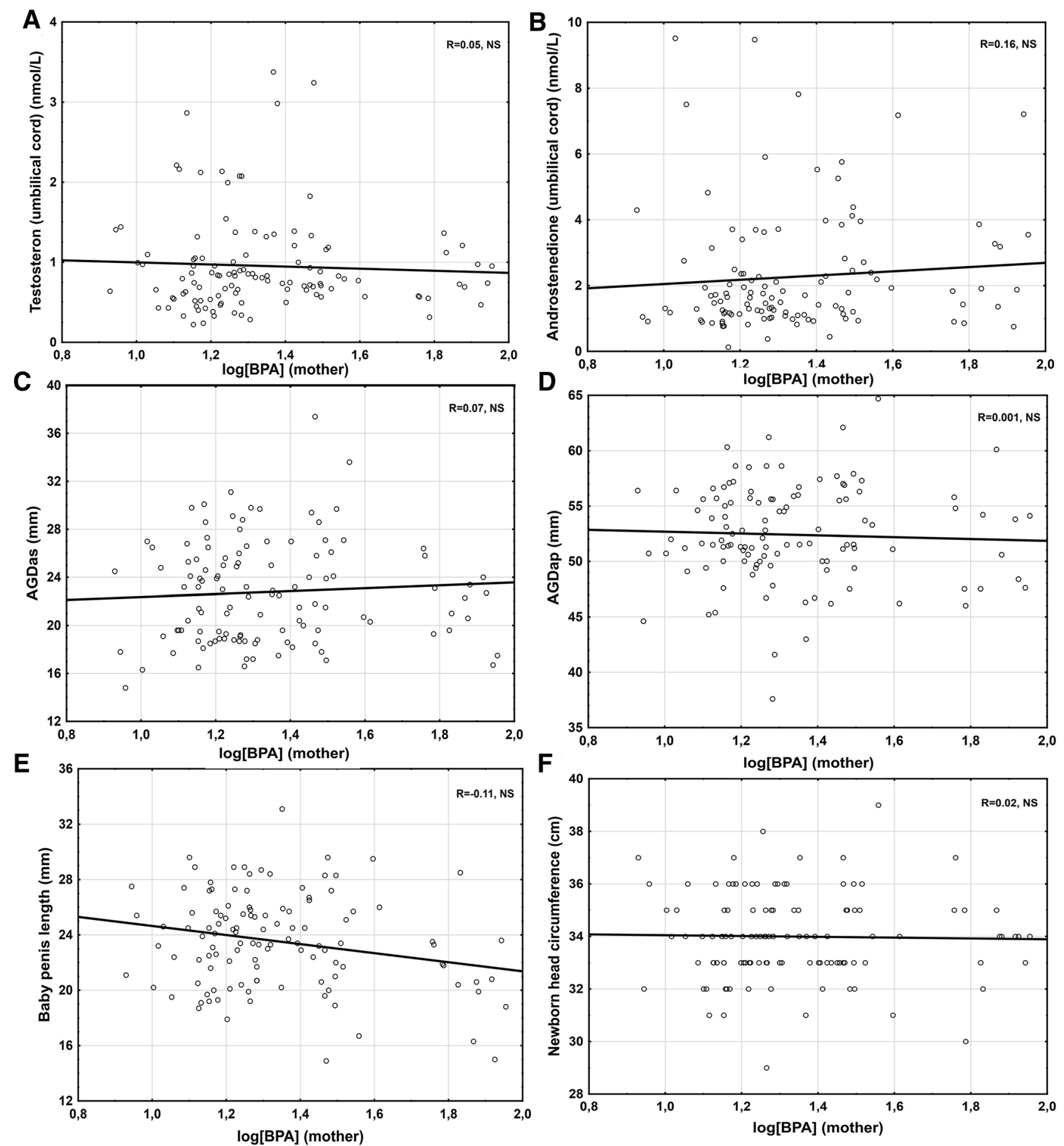

Fig. 2 Correlation between the mother's peripheral plasma BPA concentration and the umbilical cord plasma steroid hormone levels (testosterone and androstenedione), anthropometric parameters (AGDas

anogenital distance anus-scrotum, AGDap anogenital distance anuspenis, $S P L$ the stretched penile length), or newborn head circumference $(n=117 /$ group $)$ 

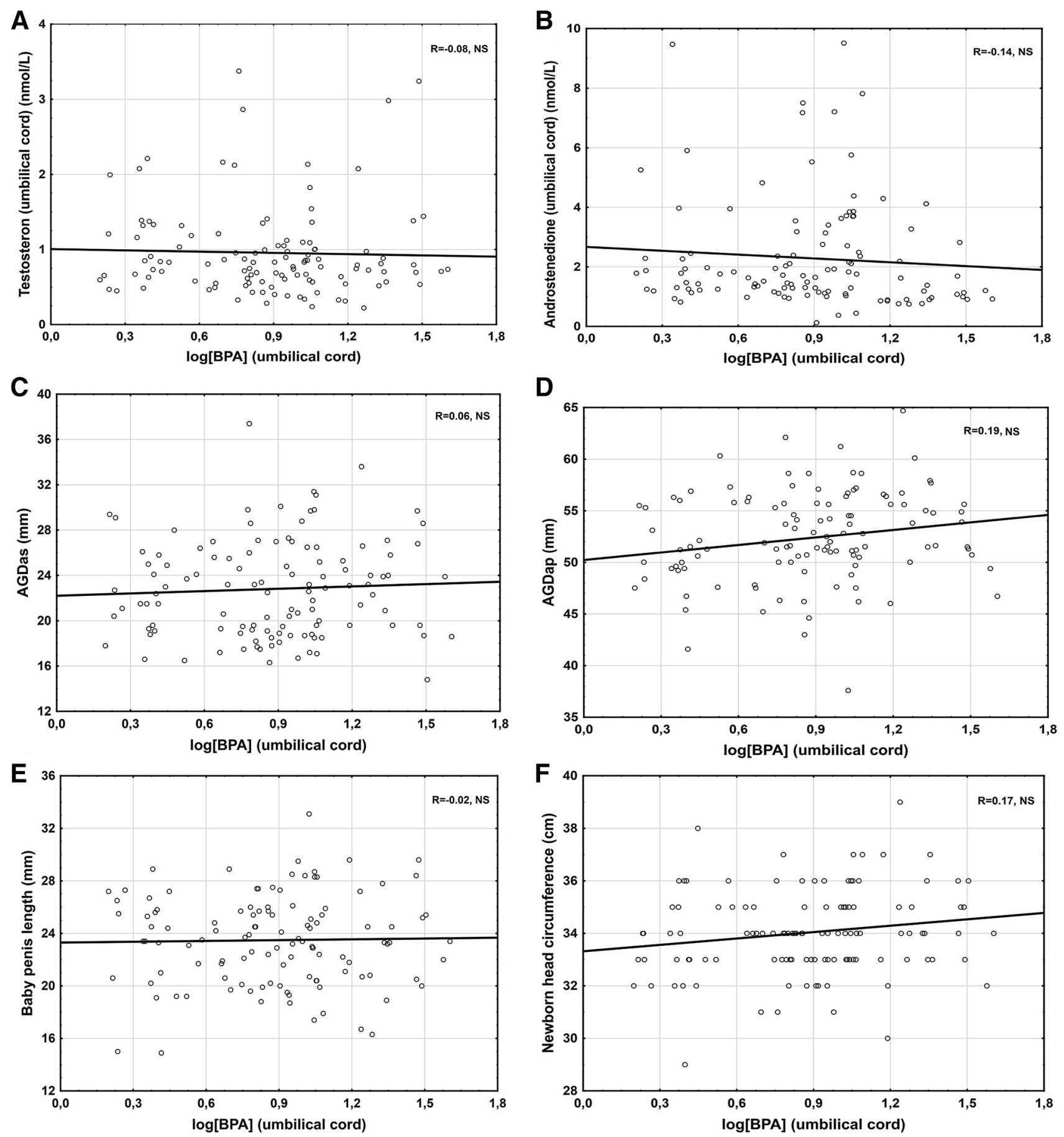

Fig. 3 Correlation between the umbilical cord peripheral plasma BPA concentration and the umbilical cord plasma steroid hormone levels (testosterone and androstenedione), anthropometric parameters

(AGDas anogenital distance anus-scrotum, AGDap anogenital distance anus-penis, $S P L$ the stretched penile length), or newborn head circumference ( $n=117$ /group)

\section{Transfer of BPA from Mother to Fetus was Significantly Reduced}

Our study confirmed statistically significantly $(p<0.001)$ higher BPA concentrations in the maternal and placental compartments as compared to cord plasma. One cannot rule 
A
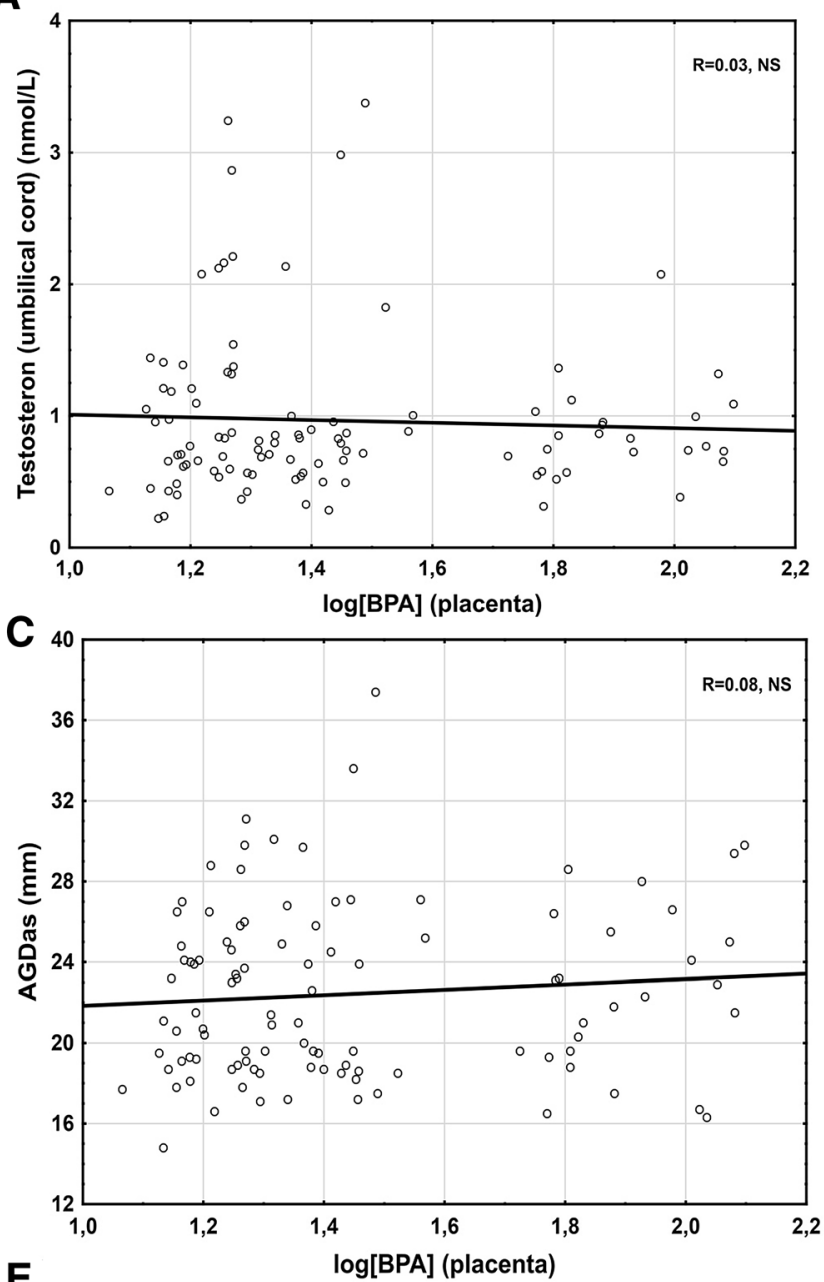

E

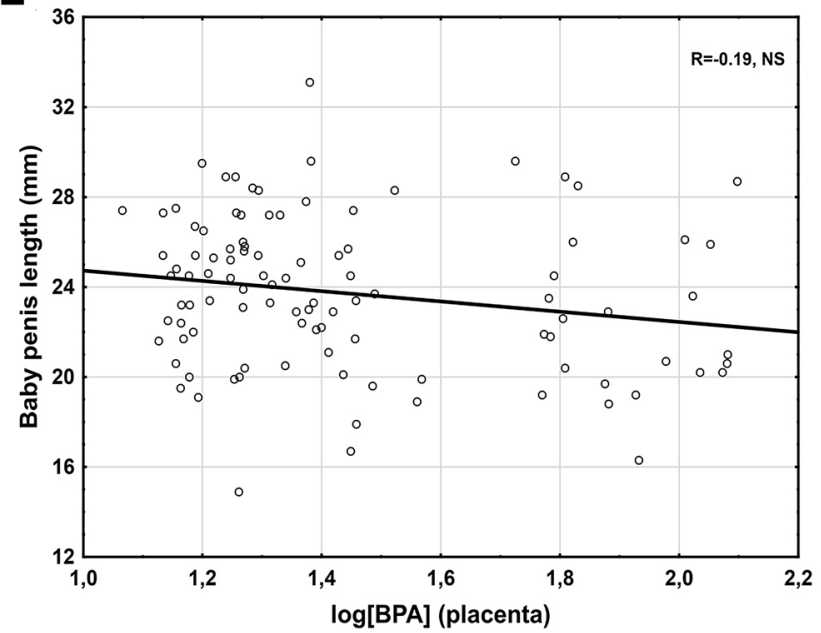

Fig. 4 Correlation between the placental tissue BPA concentration and the umbilical cord plasma steroid hormone levels (testosterone and androstenedione), anthropometric parameters (AGDas anogenital
B

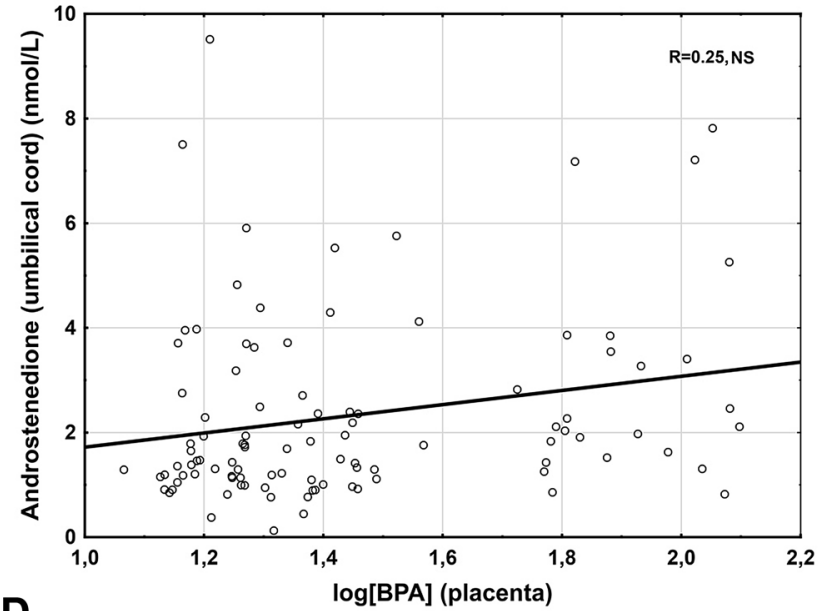

D

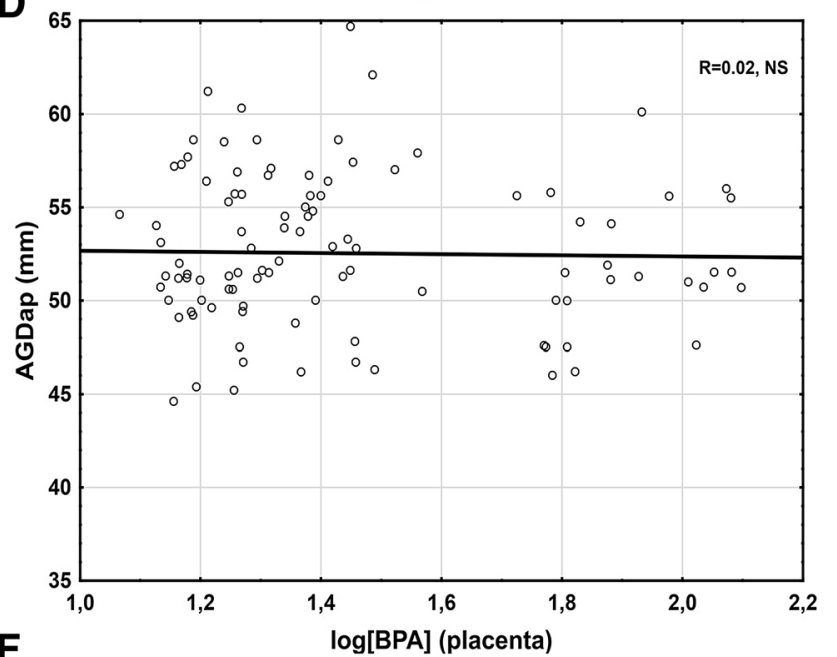

$\mathbf{F}$

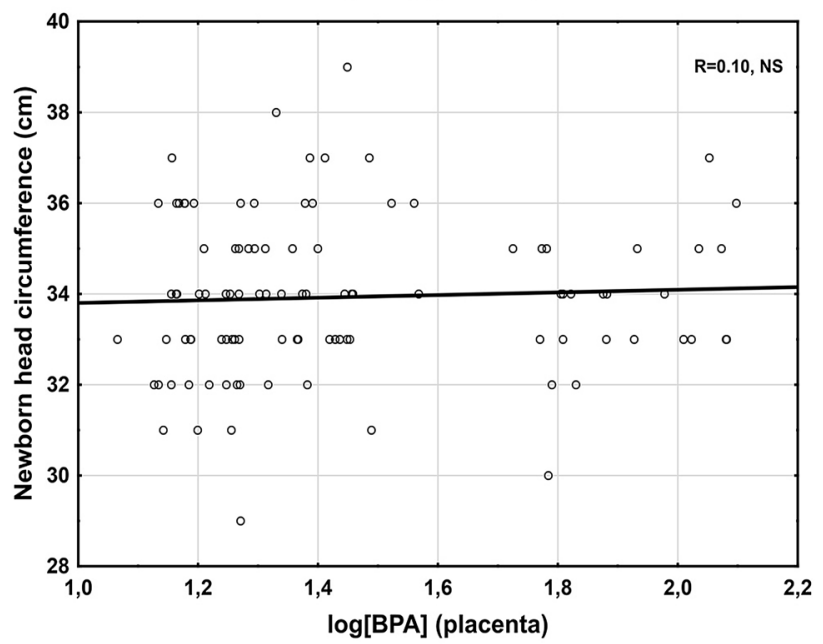

distance anus-scrotum, AGDap anogenital distance anus-penis, SPL the stretched penile length), or newborn head circumference $(n=117 /$ group) 
out that the lower concentration of BPA in the fetal could be a result of selective transfer of BPA through placenta and placental protective effect on fetal BPA exposure. However, such a potentially protective effect of the placenta on fetal BPA exposure requires further investigation throughout pregnancy.

Given that the placenta may work as a barrier between the fetus and mother in terms of BPA transport, the interaction of BPA and placenta remains largely unknown. Another group (Rajakumar et al. 2015) tested recently the impact of BPA on the placental gene expression profile in vitro. BPA stimulation of placental tissue at micromolar concentrations significantly upregulated the expression of hydroxysteroid 11-beta hydroxysteroid dehydrogenase 2 (11ß-HSD2), aromatase (CYP19A1), glucose transporter 1, corticotropinreleasing hormone, and human chorionic gonadotropin. It was suggested that BPA may affect gene expression in trophoblasts with an impact on placental function and lead to complications during pregnancy, such as miscarriages, premature labor, poor fetal growth, and increased risk of hypertension and eclampsia (Rajakumar et al. 2015). However, it should be emphasized that the BPA concentrations tested were 100-1000-fold higher than detected in placental tissue (Rajakumar et al. 2015). BPA concentrations in placental tissues of cryptorchid newborn boys with hypospadias were significantly higher that of in a group of healthy children (Fernandez et al. 2016). A statistically significant correlation between placental BPA concentration and birthweight was also reported in this cryptorchid newborn group (Fernandez et al. 2016). In another study, a negative correlation between birthweight and placental BPA levels [ranging from 17.6 to $1096 \mathrm{nmol} / \mathrm{kg}$ (mean $412 \pm 246 \mathrm{nmol} / \mathrm{kg}$ )] was shown (Troisi et al. 2014), which could not be replicated in the present study.

In adult humans, nearly all of the BPA is eliminated through urine, which takes place right after an extensive hepatic first-pass conjugation into BPA-glucuronide (BPAG) by uridine 5'-diphospho-glucuronosyltransferases, and/ or by sulfotranferases to a much less extent into BPA-sulfate (BPA-S) (Volkel et al. 2002). Due to the non-estrogenic character of the metabolites, these reactions are usually considered as detoxification (Nakagawa and Tayama 2000; Matthews et al. 2001). Animal studies have shown that at the late stage of pregnancy BPA is efficiently conjugated by the fetoplacental unit, mainly into BPA-G, which remains trapped within that organ. BPA-G could in turn possibly contribute to in situ fetal exposure to its bioactive form, due to deconjugation into parent BPA. In sheep placenta, BPA conjugation and BPA-G deconjugation activities were relatively balanced. It was suggested that a possible reactivation of BPA-G into BPA could contribute to an increased exposure to a level which can affect sensitive fetal tissues (Corbel et al. 2015). Our data suggest that the amount of BPA in fetal circulation is significantly lower than that in maternal circulation or placenta, suggesting that the placenta transfer/ deconjugation of BPA after environmental exposure makes it less harmful to the fetus than estimated.

It may be difficult to compare the BPA concentrations in serum and placental tissue, as there is no way of knowing how BPA is distributed in the placental residual blood and extracellular and intracellular spaces. The only meaningful comparison may be between the maternal and fetal/umbilical blood. Whether BPA remains in the placenta is unclear despite the studies comparing the placental and blood concentrations. We found significantly lower (2.3-fold) BPA concentrations in the fetal than maternal plasma or placental tissues. Placental tissue BPA concentrations mimic the maternal plasma concentrations, as there was no significant difference in between their levels, providing further evidence that the placental barrier protects the fetus from exposure to BPA.

\section{Environmental BPA Exposure May Not Impair Fetal Steroidogenesis}

Studies on animals have shown that the exposure of pregnant females to BPA affects testicular steroidogenesis, as well as induces abnormalities of the reproductive system, especially in terms of testicular structure and sperm quality in the male descendants (Castro et al. 2013; El-Beshbishy et al. 2013; N'Tumba-Byn et al. 2012; Nakamura et al. 2010; Nanjappa et al. 2012; Xi et al. 2011). BPA exposure decreases intratesticular testosterone levels (Castro et al. 2013; El-Beshbishy et al. 2013; N'Tumba-Byn et al. 2012; Nakamura et al. 2010; Nanjappa et al. 2012; Xi et al. 2011) and decreases steroidogenic enzyme expression (D'Cruz et al. 2012; Xi et al. 2011). The epigenetic effect of BPA resulting in decreased steroidogenic enzyme expression has been detected in subsequent rat generations (Salian et al. 2009). Importantly, the limitation of the animal BPA data is the need of micromolar (Castro et al. 2013): (El-Beshbishy et al. 2013; Nakamura et al. 2010; Xi et al. 2011) concentrations, as well as the route of gavage with 0.5-0.9 mg/kg BW doses (Fang et al. 2013; N'Tumba-Byn et al. 2012; Nanjappa et al. 2012; Wu et al. 2011) to demonstrate the harmful effects.

No association was found between cord blood BPA and sex steroid concentrations, in agreement with earlier studies (Kobayashi et al. 2010; LaRocca et al. 2011; Sanchez et al. 2013). Free BPA in cord blood has been shown to be inversely associated with INSL3, but conflicting results have been reported on the association of BPA levels with reproductive hormone concentrations, including testosterone (Fenichel et al. 2012; Galloway et al. 2010; Lassen et al. 2014; Meeker et al. 2010; Mendiola et al. 2010). Our data showed that the environmental BPA exposure did not affect any of the hormone concentrations measured, thus contradicting several earlier animal studies (see above). 


\section{No Correlation was Found Between BPA Levels and Anthropometric Parameters, Birthweight, or Infant Head Circumference}

We did not find any statistically significant correlations between AGDas or AGDap and BPA levels in maternal plasma, placental tissue, or cord plasma. AGD is considered to respond to androgen action in utero (Dean and Sharpe 2013). In animal studies, reduced androgen action due to BPA exposure during fetal life was reported to shorten AGD (Tyl et al. 2008), although all studies have not reached such conclusions (Kobayashi et al. 2010; LaRocca et al. 2011). In contrast to our negative data, a positive dose-related correlation was found between shorter AGD in babies whose mothers were exposed to BPA (AGD $8.11 \mathrm{~mm}$ shorter, $p=0.003$ ) (Miao et al. 2011). However, in this study, the mothers were exposed to higher BPA levels due to their occupation, not environmentally. Earlier, another study also reported no significant correlation between among AGD, EDC exposure, and steroid hormone concentration in cord blood (Liu et al. 2016).

We did not either find any correlation between the birthweight and BPA concentration (placenta, cord blood, or serum) in contrast to positive correlations found between BPA concentration and low birthweight in the infant cord blood from a group of 97 women $(11.0 \mathrm{nmol} / \mathrm{L} \mathrm{vs}$. $2.2 \mathrm{nmol} / \mathrm{L}$ (Chou et al. 2011) or between urine BPA concentrations and lower infant birthweight (Huo et al. 2015). A negative correlation between BPA and fetal growth and infant head circumference was shown in mothers with a BPA concentration above $18.5 \mathrm{nmol} / \mathrm{kg}$ creatinine; where the fetal weight gain was slow (Snijder et al. 2013). A negative correlation between amniotic fluid BPA and birthweight was also found (Pinney et al. 2017), although another study showed an opposite positive correlation between serum BPA levels and birthweight and height (Lee et al. 2014). An animal study showed that a concentration of $10 \mu \mathrm{g} / \mathrm{kg} / \mathrm{d}$ of BPA in pregnant mice was associated with a lower birthweight and a higher body fat content as well as perturbed glucose homeostasis in F1 and F2 male offspring (Susiarjo et al. 2015). A plausible explanation for the lack of any correlation between the birthweight and BPA concentration in the present study could be that we strictly followed the criteria to qualify the mother from very similar socioeconomic status (Development 2015; Martinson and Reichman 2016; Pilkauskas and Martinson 2014), so that it would not have an impact on birthweight. Earlier, an association between the socioeconomic status and environmental toxicants has been shown (Tyrrell et al. 2013). Hence, our study could not detect any associations of the environmental BPA exposure with any of the anthropometric parameters measured either.

A limitation of this study could be that we excluded the female infants, as some epidemiological studies report effects of other EDCs (e.g., phthalates) on both males and females (Arbuckle et al. 2018). We decided to focus on males, because many reproductive end point outcomes in male infants are easier accessible (for example, the penile measurements). Fetal body burden may not be the primary/ only mechanism by which BPA affects fetal development, as some reports demonstrate maternal thyroid hormone alterations in response to BPA, either consequent impairment of nutrient transport or oxygen supply (Bell and Ehrhardt 2002; Sur et al. 2019). Thyroid hormone levels were not measured in this study.

In the present study, there was a positive correlation between maternal weight before pregnancy and BPA levels in blood. This is a credible finding; if BPA originates from food it should accumulate more in individuals with higher BMI and higher food intake. The accumulation of BPA to adipocytes has been suggested to affect adiponectin and leptin secretion and to increase the risk of insulin resistance and obesity (Jayashree et al. 2013; Menale et al. 2017); these data are further strengthened by animal studies that showed the stimulation of adipogenesis by BPA (Somm et al. 2009) and the inhibition of adiponectin secretion by human adipocytes (Hugo et al. 2008).

\section{Conclusion}

In light of the BPA concentrations found in maternal, placental, and cord blood in this study, both the mother and the newborn are exposed to environmental BPA. However, our results suggest that the placenta may significantly reduce BPA transport from the mother to the fetus, thus protecting the fetus from environmental BPA exposure. The concentrations of BPA found in the different maternal-fetoplacental compartments were much lower than the concentrations shown to be harmful in other studies. Environmental BPA exposure showed no negative impact on fetal testicular steroidogenesis, as monitored by umbilical cord testosterone levels. In this study, no effects of BPA on anthropometric parameters were found. A limitation of our study could be that the maternal serum BPA levels were measured only once during admission to hospital for delivery; however, after anamnesis, the patients confirmed a constant environment and the same dietary habits, suggesting similar BPA levels throughout the pregnancy. Further studies on the mechanistic aspects of the placental protective role in BPA exposure towards the early gestational male programing window are needed.

Acknowledgements This work was financially supported by Polish National Science Center Grant 2012/05/B/NZ7/02391 (SW), Medical University of Bialystok Grant N/ST/ZB/18/001/1104 (NR), and European Union EU PARP Grant Cluster "NCREMFP" UDAPOIG.05.01.00-005/12-00 (SW). 
Author Contributions ML, JC, and SW designed the study concept; ML, JC, DPT, MS, MH, ENS, WW, BB, and RM analyzed and interpreted the results; ML, JC, IH, NR, and SW drafted the manuscript. All the authors have approved the final manuscript.

\section{Compliance with Ethical Standards}

Conflict of interest The authors have no conflicts of interest to declare.

Open Access This article is licensed under a Creative Commons Attribution 4.0 International License, which permits use, sharing, adaptation, distribution and reproduction in any medium or format, as long as you give appropriate credit to the original author(s) and the source, provide a link to the Creative Commons licence, and indicate if changes were made. The images or other third party material in this article are included in the article's Creative Commons licence, unless indicated otherwise in a credit line to the material. If material is not included in the article's Creative Commons licence and your intended use is not permitted by statutory regulation or exceeds the permitted use, you will need to obtain permission directly from the copyright holder. To view a copy of this licence, visit http://creativecommons.org/licenses/by/4.0/.

\section{References}

Allard PCM (2011) Bisphenol A in reproductive and developmental toxicology. Elsevier Inc, Amsterdam

Anjum S, Rahman S, Kaur M, Ahmad F, Rashid H, Ansari RA, Raisuddin S (2011) Melatonin ameliorates bisphenol A-induced biochemical toxicity in testicular mitochondria of mouse. Food Chem Toxicol 49:2849-2854. https://doi.org/10.1016/j.fct.2011.07.062

Arase $\mathrm{S}$ et al (2011) Endocrine disrupter bisphenol A increases in situ estrogen production in the mouse urogenital sinus. Biol Reprod 84:734-742. https://doi.org/10.1095/biolreprod.110.087502

Arbuckle TE et al (2018) Prenatal exposure to phthalates and phenols and infant endocrine-sensitive outcomes: the MIREC study. Environ Int 120:572-583. https://doi.org/10.1016/j.envint.2018.08.034

Bell AW, Ehrhardt RA (2002) Regulation of placental nutrient transport and implications for fetal growth. Nutr Res Rev 15:211-230. https://doi.org/10.1079/NRR200239

Calafat AM (2012) The U.S National Health and Nutrition Examination Survey and human exposure to environmental chemicals. Int J Hyg Environ Health 215:99-101. https://doi.org/10.1016/j.ijheh .2011.08.014

Carlsen E, Giwercman A, Keiding N, Skakkebaek NE (1992) Evidence for decreasing quality of semen during past 50 years. BMJ 305:609-613

Castro B, Sanchez P, Torres JM, Preda O, del Moral RG, Ortega E (2013) Bisphenol A exposure during adulthood alters expression of aromatase and 5alpha-reductase isozymes in rat prostate. PLoS ONE 8:e55905. https://doi.org/10.1371/journal.pone.0055905

Chou WC, Chen JL, Lin CF, Chen YC, Shih FC, Chuang CY (2011) Biomonitoring of bisphenol A concentrations in maternal and umbilical cord blood in regard to birth outcomes and adipokine expression: a birth cohort study in Taiwan. Environ Health 10:94. https://doi.org/10.1186/1476-069X-10-94

Combarnous Y, Nguyen TMD (2019) Comparative overview of the mechanisms of action of hormones and endocrine disruptor compounds. Toxics. https://doi.org/10.3390/toxics7010005

Corbel $\mathrm{T}$ et al (2015) Conjugation and deconjugation reactions within the fetoplacental compartment in a sheep model: a key factor determining bisphenol A fetal exposure. Drug Metab Dispos 43:467-476. https://doi.org/10.1124/dmd.114.061291
D’Cruz SC, Jubendradass R, Mathur PP (2012) Bisphenol A induces oxidative stress and decreases levels of insulin receptor substrate 2 and glucose transporter 8 in rat testis. Reprod Sci 19:163-172. https://doi.org/10.1177/1933719111415547

Dean A, Sharpe RM (2013) Clinical review: Anogenital distance or digit length ratio as measures of fetal androgen exposure: relationship to male reproductive development and its disorders. J Clin Endocrinol Metab 98:2230-2238. https://doi.org/10.1210/ jc. $2012-4057$

Development OfEC-Oa (2015) What are equivalence scales? https:// www.oecdorg/eco/growth/OECD-Note-EquivalenceScales.pdf. Accessed 23 Dec 2015

Doshi T, Mehta SS, Dighe V, Balasinor N, Vanage G (2011) Hypermethylation of estrogen receptor promoter region in adult testis of rats exposed neonatally to bisphenol A. Toxicology 289:74-82. https://doi.org/10.1016/j.tox.2011.07.011

El-Beshbishy HA, Aly HA, El-Shafey M (2013) Lipoic acid mitigates bisphenol A-induced testicular mitochondrial toxicity in rats. Toxicol Ind Health 29:875-887. https://doi.org/10.1177/07482 33712446728

Fang Y, Zhou Y, Zhong Y, Gao X, Tan T (2013) Effect of vitamin E on reproductive functions and anti-oxidant activity of adolescent male mice exposed to bisphenol A. Wei Sheng Yan Jiu 42:18-22

FDA (2012a) Bisphenol A (BPA): use in food contact application US Food and Drug Administartion. FDA, Silver Spring, MD

FDA (2012b) Use in food contact application. US Food and Drug Administartion. https://www.fda.gov/newsevents/publichealthfoc us/ucm064437.htm.

Fenichel P et al (2012) Unconjugated bisphenol A cord blood levels in boys with descended or undescended testes. Hum Reprod 27:983-990. https://doi.org/10.1093/humrep/der451

Fenichel P, Chevalier N, Brucker-Davis F (2013) Bisphenol A: an endocrine and metabolic disruptor. Ann Endocrinol (Paris) 74:211-220. https://doi.org/10.1016/j.ando.2013.04.002

Fernandez MF et al (2016) Bisphenol A and other phenols in human placenta from children with cryptorchidism or hypospadias. Reprod Toxicol 59:89-95. https://doi.org/10.1016/j.repro tox.2015.11.002

Galloway T et al (2010) Daily bisphenol A excretion and associations with sex hormone concentrations: results from the InCHIANTI adult population study. Environ Health Perspect 118:1603-1608. https://doi.org/10.1289/ehp.1002367

Gatimel N, Lacroix MZ, Chanthavisouk S, Picard-Hagen N, Gayrard V, Parinaud J, Leandri RD (2016) Bisphenol A in culture media and plastic consumables used for ART. Hum Reprod 31:1436-1444. https://doi.org/10.1093/humrep/dew116

Gould JC et al (1998) Bisphenol A interacts with the estrogen receptor alpha in a distinct manner from estradiol. Mol Cell Endocrinol 142:203-214

Hugo ER, Brandebourg TD, Woo JG, Loftus J, Alexander JW, BenJonathan N (2008) Bisphenol A at environmentally relevant doses inhibits adiponectin release from human adipose tissue explants and adipocytes. Environ Health Perspect 116:1642-1647. https:// doi.org/10.1289/ehp.11537

Huo W et al (2015) Maternal urinary bisphenol A levels and infant low birth weight: a nested case-control study of the Health Baby Cohort in China. Environ Int 85:96-103. https://doi.org/10.1016/j. envint.2015.09.005

Ikezuki Y, Tsutsumi O, Takai Y, Kamei Y, Taketani Y (2002) Determination of bisphenol A concentrations in human biological fluids reveals significant early prenatal exposure. Hum Reprod 17:2839-2841

Jayashree S, Indumathi D, Akilavalli N, Sathish S, Selvaraj J, Balasubramanian K (2013) Effect of Bisphenol-A on insulin signal transduction and glucose oxidation in liver of adult male albino rat. 
Environ Toxicol Pharmacol 35:300-310. https://doi.org/10.1016/j. etap.2012.12.016

Jin P, Wang X, Chang F, Bai Y, Li Y, Zhou R, Chen L (2013) Low dose bisphenol A impairs spermatogenesis by suppressing reproductive hormone production and promoting germ cell apoptosis in adult rats J. Biomed Res 27:135-144. https://doi.org/10.7555/ JBR.27.20120076

Jorgensen $\mathrm{N}$ et al (2012) Human semen quality in the new millennium: a prospective cross-sectional population-based study of $4867 \mathrm{men}$. BMJ Open. https://doi.org/10.1136/bmjopen-2012-000990

Kobayashi K, Ohtani K, Kubota H, Miyagawa M (2010) Dietary exposure to low doses of bisphenol A: effects on reproduction and development in two generations of C57BL/6J mice. Congenit Anom (Kyoto) 50:159-170. https://doi.org/10.111 1/j.1741-4520.2010.00279.x

Kolatorova L et al (2018) Exposure to bisphenols and parabens during pregnancy and relations to steroid changes. Environ Res 163:115122. https://doi.org/10.1016/j.envres.2018.01.031

Kuroda N et al (2003) Measurement of bisphenol A levels in human blood serum and ascitic fluid by HPLC using a fluorescent labeling reagent. J Pharm Biomed Anal 30:1743-1749

LaRocca J, Boyajian A, Brown C, Smith SD, Hixon M (2011) Effects of in utero exposure to Bisphenol A or diethylstilbestrol on the adult male reproductive system. Birth Defects Res B 92:526-533. https://doi.org/10.1002/bdrb.20336

Lassen TH et al (2014) Urinary bisphenol A levels in young men: association with reproductive hormones and semen quality. Environ Health Perspect 122:478-484. https://doi.org/10.1289/ehp.13073 09

Lee BE et al (2014) Prenatal bisphenol A and birth outcomes: MOCEH (Mothers and Children's Environmental Health) study. Int J Hyg Environ Health 217:328-334. https://doi.org/10.1016/j.ijheh .2013 .07 .005

Lee $\mathrm{J}$ et al (2018) Bisphenol A distribution in serum, urine, placenta, breast milk, and umbilical cord serum in a birth panel of motherneonate pairs. Sci Total Environ 626:1494-1501. https://doi. org/10.1016/j.scitotenv.2017.10.042

Li X, Li H, Jia L, Li X, Rahman N (2015) Oestrogen action and male fertility: experimental and clinical findings. Cell Mol Life Sci 72:3915-3930. https://doi.org/10.1007/s00018-015-1981-4

Liu C et al (2013) Exposure to bisphenol A disrupts meiotic progression during spermatogenesis in adult rats through estrogen-like activity. Cell Death Dis 4:e676. https://doi.org/10.1038/cddis .2013 .203

Liu C, Xu X, Zhang Y, Li W, Huo X (2016) Associations between maternal phenolic exposure and cord sex hormones in male newborns. Hum Reprod 31:648-656. https://doi.org/10.1093/humre $\mathrm{p} / \mathrm{dev} 327$

Martinson ML, Reichman NE (2016) Socioeconomic inequalities in low birth weight in the United States, the United Kingdom, Canada, and Australia. Am J Public Health 106:748-754. https://doi. org/10.2105/AJPH.2015.303007

Mathews TJ, Hamilton BE (2005) Trend analysis of the sex ratio at birth in the United States. Natl Vital Stat Rep 53:1-17

Matthews JB, Twomey K, Zacharewski TR (2001) In vitro and in vivo interactions of bisphenol A and its metabolite, bisphenol A glucuronide, with estrogen receptors $\alpha$ and $\beta$. Chem Res Toxicol 14(2):149-157. https://doi.org/10.1021/tx0001833

McLachlan JA, Newbold RR, Bullock B (1975) Reproductive tract lesions in male mice exposed prenatally to diethylstilbestrol. Science 190:991-992

Medwid S, Guan H, Yang K (2016) Prenatal exposure to bisphenol A disrupts adrenal steroidogenesis in adult mouse offspring. Environ Toxicol Pharmacol 43:203-208. https://doi.org/10.1016/j. etap.2016.03.014
Meeker JD, Calafat AM, Hauser R (2010) Urinary bisphenol A concentrations in relation to serum thyroid and reproductive hormone levels in men from an infertility clinic. Environ Sci Technol 44:1458-1463. https://doi.org/10.1021/es9028292

Menale C et al (2017) Bisphenol A is associated with insulin resistance and modulates adiponectin and resistin gene expression in obese children. Pediatr Obes 12:380-387. https://doi.org/10.1111/ ijpo. 12154

Mendiola J et al (2010) Are environmental levels of bisphenol A associated with reproductive function in fertile men? Environ Health Perspect 118:1286-1291. https://doi.org/10.1289/ehp.1002037

Miao M et al (2011) utero exposure to bisphenol-A and anogenital distance of male offspring. Birth Defects Res A 91:867-872. https ://doi.org/10.1002/bdra.22845

Molina-Molina JM et al (2013) vitro study on the agonistic and antagonistic activities of bisphenol-S and other bisphenol-A congeners and derivatives via nuclear receptors. Toxicol Appl Pharmacol 272:127-136. https://doi.org/10.1016/j.taap.2013.05.015

N'Tumba-Byn T et al (2012) Differential effects of bisphenol A and diethylstilbestrol on human, rat and mouse fetal leydig cell function. PLoS ONE 7:e51579. https://doi.org/10.1371/journ al.pone.0051579

Nakagawa Y, Tayama S (2000) Metabolism and cytotoxicity of bisphenol A and other bisphenols in isolated rat hepatocytes. Arch Toxicol 74(2):99-105. https://doi.org/10.1007/s002040050659

Nakamura D et al (2010) Bisphenol A may cause testosterone reduction by adversely affecting both testis and pituitary systems similar to estradiol. Toxicol Lett 194:16-25. https://doi. org/10.1016/j.toxlet.2010.02.002

Nanjappa MK, Simon L, Akingbemi BT (2012) The industrial chemical bisphenol A (BPA) interferes with proliferative activity and development of steroidogenic capacity in rat. Leydig cells Biol Reprod 86:131-112. https://doi.org/10.1095/biolreprod .111 .095349

Pilkauskas NV, Martinson ML (2014) Three-generation family households in early childhood: comparisons between the United States, the United Kingdom, and Australia. Demogr Res 30:1639-1652. https://doi.org/10.4054/DemRes.2014.30.60

Pinney SE et al (2017) Second trimester amniotic fluid bisphenol A concentration is associated with decreased birth weight in term infants. Reprod Toxicol 67:1-9. https://doi.org/10.1016/j.repro tox.2016.11.007

Rajakumar C, Guan H, Langlois D, Cernea M, Yang K (2015) Bisphenol A disrupts gene expression in human placental trophoblast cells. Reprod Toxicol 53:39-44. https://doi.org/10.1016/j. reprotox.2015.03.001

Rochester JR (2013) Bisphenol A and human health: a review of the literature. Reprod Toxicol 42:132-155. https://doi. org/10.1016/j.reprotox.2013.08.008

Routledge EJ, White R, Parker MG, Sumpter JP (2000) Differential effects of xenoestrogens on coactivator recruitment by estrogen receptor (ER) alpha and ERbeta. J Biol Chem 275:3598635993. https://doi.org/10.1074/jbc.M006777200

Rubin BS (2011) Bisphenol A: an endocrine disruptor with widespread exposure and multiple effects. J Steroid Biochem Mol Biol 127:27-34. https://doi.org/10.1016/j.jsbmb.2011.05.002

Salian S, Doshi T, Vanage G (2009) Perinatal exposure of rats to Bisphenol A affects the fertility of male offspring. Life Sci 85:742-752. https://doi.org/10.1016/j.lfs.2009.10.004

Sanchez P, Castro B, Torres JM, Olmo A, del Moral RG, Ortega E (2013) Bisphenol A modifies the regulation exerted by testosterone on 5 alpha -reductase isozymes in ventral prostate of adult rats. Biomed Res Int 2013:629235. https://doi. org/10.1155/2013/629235

Schonfelder G, Wittfoht W, Hopp H, Talsness CE, Paul M, Chahoud I (2002) Parent bisphenol A accumulation in the 
human maternal-fetal-placental unit. Environ Health Perspect 110:A703-707

Sharpe RM, Irvine DS (2004) How strong is the evidence of a link between environmental chemicals and adverse effects on human reproductive health? BMJ 328:447-451. https://doi. org/10.1136/bmj.328.7437.447

Shekhar S et al (2017) Detection of phenolic endocrine disrupting chemicals (EDCs) from maternal blood plasma and amniotic fluid in Indian population. Gen Comp Endocrinol 241:100-107. https://doi.org/10.1016/j.ygcen.2016.05.025

Shelnutt S, Kind J, Allaben W (2013) Bisphenol A: update on newly developed data and how they address NTP's 2008 finding of "Some Concern". Food Chem Toxicol 57:284-295. https://doi. org/10.1016/j.fct.2013.03.027

Skakkebaek NE, Rajpert-De Meyts E, Main KM (2001) Testicular dysgenesis syndrome: an increasingly common developmental disorder with environmental aspects. Hum Reprod 16:972-978

Skakkebaek NE et al (2016) Male reproductive disorders and fertility trends: influences of environment and genetic susceptibility. Physiol Rev 96:55-97. https://doi.org/10.1152/physrev.00017 .2015

Skinner MK (2011a) Environmental epigenetic transgenerational inheritance and somatic epigenetic mitotic stability. Epigenetics 6:838-842

Skinner MK (2011b) Environmental epigenomics and disease susceptibility. EMBO Rep 12:620-622. https://doi.org/10.1038/embor .2011 .125

Skinner MK (2011c) Role of epigenetics in developmental biology and transgenerational inheritance. Birth Defects Res C 93:51-55. https ://doi.org/10.1002/bdrc.20199

Snijder CA et al (2013) Fetal growth and prenatal exposure to bisphenol A: the generation R study. Environ Health Perspect 121:393398. https://doi.org/10.1289/ehp.1205296

Somm E et al (2009) Perinatal exposure to bisphenol a alters early adipogenesis in the rat. Environ Health Perspect 117:1549-1555. https://doi.org/10.1289/ehp.11342

Sur U, Erkekoglu P, Bulus AD, Andiran N, Kocer-Gumusel B (2019) Oxidative stress markers, trace elements, and endocrine disrupting chemicals in children with Hashimoto's thyroiditis. Toxicol Mech Methods. https://doi.org/10.1080/15376516.2019.1646367

Susiarjo M, Xin F, Bansal A, Stefaniak M, Li C, Simmons RA, Bartolomei MS (2015) Bisphenol a exposure disrupts metabolic health across multiple generations in the mouse. Endocrinology 156:2049-2058. https://doi.org/10.1210/en.2014-2027

Teeguarden JG, Twaddle NC, Churchwell MI, Doerge DR (2016) Urine and serum biomonitoring of exposure to environmental estrogens I: bisphenol A in pregnant women. Food Chem Toxicol 92:129142. https://doi.org/10.1016/j.fct.2016.03.023

Thayer KA et al (2015) Pharmacokinetics of bisphenol A in humans following a single oral administration. Environ Int 83:107-115. https://doi.org/10.1016/j.envint.2015.06.008

Toppari J et al (1996) Male reproductive health and environmental xenoestrogens. Environ Health Perspect 104(Suppl 4):741-803. https://doi.org/10.1289/ehp.96104s4741

Toppari J, Virtanen HE, Main KM, Skakkebaek NE (2010) Cryptorchidism and hypospadias as a sign of testicular dysgenesis syndrome (TDS): environmental connection. Birth Defects Res A 88:910-919. https://doi.org/10.1002/bdra.20707

Troisi J, Mikelson C, Richards S, Symes S, Adair D, Zullo F, Guida M (2014) Placental concentrations of bisphenol A and birth weight from births in the Southeastern U.S. Placenta 35:947-952. https ://doi.org/10.1016/j.placenta.2014.08.091

Tyl RW et al (2008) Two-generation reproductive toxicity study of dietary bisphenol A in CD-1 (Swiss) mice. Toxicol Sci 104:362-384. https://doi.org/10.1093/toxsci/kfn084

Tyrrell J, Galloway TS, Abo-Zaid G, Melzer D, Depledge MH, Osborne NJ (2013) High urinary tungsten concentration is associated with stroke in the National Health and Nutrition Examination Survey 1999-2010. PLoS ONE 8:e77546. https://doi.org/10.1371/journ al.pone. 0077546

Vandenberg LN (2014) Hazards of food contact material: bisphenol A and endocrine disruption in Encyclopedia of Food Safety. Elsevier, Amsterdam

Vandenberg LN, Hauser R, Marcus M, Olea N, Welshons WV (2007) Human exposure to bisphenol A (BPA). Reprod Toxicol 24:139177. https://doi.org/10.1016/j.reprotox.2007.07.010

Vandenberg LN, Chahoud I, Heindel JJ, Padmanabhan V, Paumgartten FJ, Schoenfelder G (2012) Urinary, circulating, and tissue biomonitoring studies indicate widespread exposure to bisphenol A. Cien Saude Colet 17:407-434

Virtanen HE, Jorgensen N, Toppari J (2017) Semen quality in the 21(st) century. Nat Rev Urol 14:120-130. https://doi.org/10.1038/nruro 1.2016 .261

Volkel W, Colnot T, Csanady GA, Filser JG, Dekant W (2002) Metabolism and kinetics of bisphenol a in humans at low doses following oral administration. Chem Res Toxicol 15:1281-1287

vom Saal FS et al (2007) Chapel Hill bisphenol A expert panel consensus statement: integration of mechanisms, effects in animals and potential to impact human health at current levels of exposure. Reprod Toxicol 24:131-138. https://doi.org/10.1016/j.repro tox.2007.07.005

Vrooman LA, Oatley JM, Griswold JE, Hassold TJ, Hunt PA (2015) Estrogenic exposure alters the spermatogonial stem cells in the developing testis, permanently reducing crossover levels in the adult. PLoS Genet 11:e1004949. https://doi.org/10.1371/journ al.pgen.1004949

Wang Q et al (2010) Mitochondrial signaling pathway is also involved in bisphenol A induced germ cell apoptosis in testes. Toxicol Lett 199:129-135. https://doi.org/10.1016/j.toxlet.2010.08.014

Wu JH, Jiang XR, Liu GM, Liu XY, He GL, Sun ZY (2011) Oral exposure to low-dose bisphenol A aggravates testosterone-induced benign hyperplasia prostate in rats. Toxicol Ind Health 27:810 819. https://doi.org/10.1177/0748233711399310

Xi W et al (2011) Effect of perinatal and postnatal bisphenol A exposure to the regulatory circuits at the hypothalamus-pituitarygonadal axis of CD-1 mice. Reprod Toxicol 31:409-417. https:// doi.org/10.1016/j.reprotox.2010.12.002

Yamamoto J, Minatoya M, Sasaki S, Araki A, Miyashita C, Matsumura T, Kishi R (2016) Quantifying bisphenol A in maternal and cord whole blood using isotope dilution liquid chromatography/tandem mass spectrometry and maternal characteristics associated with bisphenol A. Chemosphere 164:25-31. https://doi.org/10.1016/j. chemosphere.2016.08.001

Publisher's Note Springer Nature remains neutral with regard to jurisdictional claims in published maps and institutional affiliations. 


\section{Affiliations}

\section{Monika Lukasiewicz ${ }^{1}$. Jan Czerniecki ${ }^{2}$. Donata Ponikwicka-Tyszko ${ }^{2} \cdot$ Maria Sztachelska $^{2} \cdot$ Marta Hryniewicka $^{3}$.} Edyta Nalewajko-Sieliwoniuk ${ }^{4} \cdot$ Wieslaw Wiczkowski ${ }^{5} \cdot$ Beata Banaszewska $^{6} \cdot$ Robert Milewski $^{7} \cdot$ Jorma Toppari $^{8,9}$. Ilpo Huhtaniemi ${ }^{10} \cdot$ Nafis A. Rahman ${ }^{1,8} \cdot$ Slawomir Wolczynski ${ }^{1,2}$ (])

$1 \quad$ Department of Reproduction and Gynecological

Endocrinology, Medical University of Bialystok, Białystok,

Poland

2 Department of Biology and Pathology of Human Reproduction, Institute of Animal Reproduction and Food Research, Polish Academy of Sciences, Olsztyn, Poland

3 Department of General and Inorganic Chemistry, Institute of Chemistry, University of Bialystok, Białystok, Poland

4 Department of Analytical Chemistry, Institute of Chemistry, University of Bialystok, Białystok, Poland

5 Department of Chemistry and Biodynamics of Food, Institute of Animal Reproduction and Food Research, Polish Academy of Sciences, Olsztyn, Poland
6 Division of Infertility and Reproductive Endocrinology, Department of Gynecology, Obstetrics and Gynecological Oncology, Poznan University of Medical Sciences, Poznan, Poland

7 Department of Statistics and Medical Informatics, Medical University of Bialystok, Bialystok, Poland

8 Institute of Biomedicine, University of Turku, Turku, Finland

9 Department of Pediatrics, Turku University Hospital, Turku, Finland

10 Department of Surgery \& Cancer, Institute of Reproductive and Developmental Biology, Imperial College London, London, UK 